\title{
MUSLIMAH BERCADAR (STUDI TENTANG PROSES INTERNALISASI DAN ADAPTASI SOSIAL MAHASISWI MUSLIMAH BERCADAR DI FAKULTAS EKONOMI UNIVERSITAS NEGERI MAKASSAR)
}

\author{
Marta Suharsih $^{1}$, Sopian Tamrin ${ }^{2}$ \\ ${ }^{1}$ Mahasiswa Jurusan Sosiologi Fakultas Ilmu Sosial \\ Universitas Negeri Makassar. \\ martasuharsih11@gmail.com \\ ${ }^{2}$ Dosen Sosiologi/ Universitas Negeri Makkassar \\ Email: sopian.thamrin@unm.ac.id
}

\begin{abstract}
ABSTRAK
Penelitian ini bertujuan untuk mengetahui: 1) proses internalisasi mahasiswi muslimah bercadar, 2) adaptasi sosial mahasiswi muslimah bercadar di Fakultas Ekonomi Universitas Negeri Makassar. Jenis penelitian ini adalah penelitian kualitatif deskriptif. Jumlah informan sebanyak 5 orang. Pemilihan informan dalam penelitian ini dengan cara purposive sampling dengan kriteria informan: a) mahasiswi Fakultas Ekonomi Universitas Negeri Makassar angkatan 2015-2017, b) mahasiswi muslimah bercadar, c) telah menggunakan cadar selama $>5$ bulan. Teknik pengumpulan data yang digunakan yaitu observasi, wawancara dan dokumentasi. Teknik analisis data menggunakan reduksi data, penyajian data serta penarikan kesimpulan dan verifikasi. Teknik pengabsahan data menggunakan ketekunana pengamatan dan triangulasi. Hasil penelitian menunjukkan bahwa: 1) proses internalisasi mahasiswi muslimah bercadar di Fakultas Ekonomi Universitas Negeri Makassar dilakukan dengan melalui beberapa tahap yaitu tahap menyimak, tahap menanggapi, tahap menilai, tahap mengorganisasi dan tahap karakterisasi. 2) adaptasi sosial mahasiswi muslimah bercadar dilakukan dengan : a) Penampilan nyata; diwujudkan dalam bentuk keterampilan menjalin hubungan dan kesediaan untuk terbuka pada orang lain, b) Penyesuaian diri dengan kelompok; diwujudkan dalam bentuk kerjasama dan tanggungjawab sosial, c) Sikap sosial; diwujudkan dalam bentuk berpartisipasi dalam kegiatan sosial, berempati, serta dapat menghormati dan menghargai orang lain.
\end{abstract}

Kata Kunci : Mahasiswi Muslimah Bercadar, Proses Internalisasi, dan Adaptasi Sosial.

\begin{abstract}
This study aims to determine: 1) the process of internalization of veiled Muslim female students, 2) social adaptation of veiled Muslim female students at the Faculty of Economics, Makassar State University. This type of research is descriptive qualitative research. The number of informants is 5 people. The selection of informants in this study by means of purposive sampling with the criteria of informants: a) students of the Faculty of Economics, Makassar State University class of 2015-2017, b) veiled Muslim female students, c) had used a veil for > 5 months. Data collection techniques used are observation, interviews and documentation. Data
\end{abstract}


analysis techniques using data reduction, data presentation and drawing conclusions and verification. The data validation technique uses persistence of observation and triangulation. The results showed that: 1) the process of internalization of veiled Muslim female students at the Faculty of Economics, Makassar State University was carried out through several stages, namely the listening, responding, evaluating, organizing and characterization stages. 2) social adaptation of veiled Muslim female students is done by: a) Real appearance; manifested in the form of relationship skills and a willingness to be open to others, b) Adjustment to the group; manifested in the form of cooperation and social responsibility, c) social attitude; manifested in the form of participating in social activities, empathizing, and being able to respect and respect others.

Keywords : Muslim women veiled, internalization process, and social adaptation

\section{PENDAHULUAN}

Agama Islam sangat memuliakan dan mengagungkan kedudukan kaum perempuan. Salah satunya ialah cara Islam melindungi kaum perempuan yaitu bagaimana seharusnya ia berpenampilan, dalam hal ini adab-adab menutup aurat yang sesuai dengan syariat Islam. Dalam hal berpenampilan, perempuan muslimah memiliki adab- adab syar'i dalam menutup aurat, salah satunya dengan menggunakan Jilbab Syar'i. Hal tersebut berdasarkan firman Allah SWT yang terdapat dalam Q.S Al-Ahzab (33) ayat 59 yang artinya :

"Hai Nabi, katakanlah kepada istri-istrimu, anak-anakmu, anak-anak perempuanmu, dan istri-istri orang mukmin, hendaklah mereka mengulurkan jilbabnya ke seluruh tubuh mereka. Yang demikian itu supaya mereka lebih mudah untuk dikenali karena itu mereka tidak diganggu. Dan Allah adalah Maha Pengampun lagi Maha Penyayang"

Terdapat dua bentuk cara berbusana yang dipandang Islami dan sesuai dengan syariat bagi seorang perempuan yaitu dengan menutup seluruh tubuh pakaian disertai cadar (mutahjjibah), dan tidak disertai dengan cadar dengan kedua tangan dan wajah terbuka. Cadar adalah kain penutup muka atau sebagian wajah wanita, hanya matanya saja yang tampak dalam bahasa Arabnya khidr, tsiqab. Oleh Abu Ubaid(As Salam,2012), niqab menurut orang arab adalah penutup wajah yang menampakkan kedua mata dan disebut pula dengan wushushah atau burqa'. Sementara dalam Kamus Besar Bahasa Indonesia, cadar berarti kain penutup kepala.

Dalam penerapannya, muslimah yang menggunakan cadar merupakan kondisi yang terus berkembang di Indonesia, khususnya di wilayah kota Makassar. Salah satunya ditandai dengan beberapa muslimah bercadar yang saat ini masuk dalam berbagai ruang lingkup sosial, termasuk dalam lingkup Lembaga Pendidikan, seperti di Perguruan Tinggi Universitas Negeri Makassar.

Pengambilan keputusan untuk memilih identitas baru melalui proses internalisasi yang dilakukan oleh mahasiswi muslimah bercadar memiliki resiko yang besar bagi kehidupan sosialnya. Mengingat keberadaan perempuan bercadar dalam konteks sosial masih belum dapat diterima penuh oleh sebagian masyarakat dan dengan jumlah yang masih menjadi kaum minoritas khususnya di Universitas Negeri Makassar. Sehingga, melalui proses internalisasi yang kokoh, dalam pengambilan keputusan untuk menggunakan cadar, para muslimah bercadar juga harus mampu beradaptasi terhadap lingkungannya, baik dalam lingkup perkuliahan maupun dalam masyarakat umum.

Berdasarkan uraian latar belakang masalah yang telah di paparkan diatas, maka penulis tertarik untuk melakukan penelitian dengan judul muslimah bercadar (studi tentang proses internalisasi dan adaptasi sosial mahasiswi muslimah bercadar di Fakultas Ekonomi Universitas Negeri Makassar) dan mengangkat masalah yang dikaji adalah tentang proses internalisasi mahasiswi muslimah bercadar di fakultas ekonomi universitas negeri makassar dan adaptasi sosial 
mahasiswi muslimah bercadar di Fakultas Ekonomi Universitas Negeri Makassar.

\section{METODE}

Jenis penelitian ini adalah penelitian kualitatif deskriptif. Jumlah informan sebanyak 5 orang. Pemilihan informan dalam penelitian ini dengan cara purposive sampling dengan kriteria informan: a) mahasiswi Fakultas Ekonomi Universitas Negeri Makassar angkatan 2015-2017, b) mahasiswi muslimah bercadar, c) telah menggunakan cadar selama $>5$ bulan. Teknik pengumpulan data yang digunakan yaitu observasi, wawancara dan dokumentasi. Teknik analisis data menggunakan reduksi data, penyajian data serta penarikan kesimpulan dan verifikasi. Teknik pengabsahan data menggunakan ketekunana pengamatan dan triangulasi.

\section{HASIL DAN PEMBAHASAN}

\section{Kajian teori konstruksi Sosial}

Teori yang dikembangkan oleh Peter L Berger ini berangkat dari paradigma konstruktivis yang memandang realitas sosial merupakan konstruksi sosial yang diciptakan oleh individu. Istilah konstruksi sosial atas realitas didefinisikan sebagai proses sosial melalui tindakan dan interaksi dimana individu menciptakan secara terus-menerus suatu realitas yang dialami bersama secara subjektif (Poloma, 2003). Teori ini melihat bahwa masyarakat memiliki konstruksi sebagai realitas objektif sekaligus subjektif. Konsepsi tentang realitas individu dihasilkan dari interaksi antara individu dengan masyarakat. Individu secara efektif dan kreatif mengembangkan dirinya melalui respon-respon terhadap stimulus dalam dunia kognitifnya (Bungin, 2001).

Melalui proses dialektika ini, realitas sosial dapat dilihat dari tiga tahap tersebut. Pertama, eksternalisasi adalah usaha pencurahan atau ekspresi diri manusia kedalam dunia sosio- kultural, baik dalam kegiatan mental maupun fisik. Proses ini merupakan ekspresi diri untuk menguatkan eksistensi individu dalam masyarakat, dengan kata lain disebut proses penyesuaian diri dengan sosio-kultural. Tahap eksternaliasasi berlangsung ketika produk sosial tercipta di dalam masyarakat, kemudian individu mengeksternalisasikan (penyesuaian diri) ke dalam dunia sosiokulturalnya. Kedua, objektivasi adalah hasil yang telah dicapai baik mental maupun fisik dari kegiatan eksternalisasi manusia tersebut. Hasil itu berupa realitas yang objektif, yang berbeda dengan kenyataan subjektif perorangan. Pada tahap ini masyarakat dilihat sebagai realitas yang objektif atau proses interaksi sosial dalam dunia intersubjektif yang dilembagakan atau mengalami proses institusionalisasi. Hal terpenting dari objektivasi adalah pembuatan signifikasi yaitu pembatasan tanda-tanda oleh manusia. Ketiga, internalisasi adalah pemahaman individu mengenai dunia sebagai sesuatu yang maknawi dari kenyataan sosial atau lebih pada penyerapan kembali dunia objektif kedalam kesadaran sehingga subjektif individu dipengaruhi oleh struktur dunia sosial, dengan kata lain realitas sosial itu berada di dalam diri manusia dan dengan cara itu manusia akan teridentifikasi di dalam dunia sosio-kulturalnya.

Dalam Kamus Besar Bahasa Indonesia, internalisasi diartikan sebagai penghayatan, pendalaman, penguasaan secara mendalam yang berlangsung melalui pembinaan, bimbingan, dan sebagainya. ${ }^{6}$ Penghayatan terhadap suatu ajaran, doktrin, atau nilai sehingga merupakan keyakinan dan kesadaran akan kebenaran doktrin atau nilai yang diwujudkan dalam sikap dan perilaku. Secara Sosiologis, Scott (1971) menyatakan pendapatnya tentang Internalisasi yakni :

"Internalisasi melibatkan sesuatu yakni ide, konsep dan tindakan yang bergerak dari luar ke suatu tempat di dalam mindah (pikiran) dari suatu kepribadian. Struktur dan kejadian di dalam masyarakat lazim membentuk pribadi yang dalam diri seseorang sehingga terjadi internalisasi ${ }^{\prime \prime}$

Proses internalisasi hakikatnya adalah sebuah proses menanamkan sesuatu, keyakinan, sikap dan nilai- nilai yang menjadi perilaku sosial. Namun proses penanaman tersebut tumbuh dari dalam diri seseorang sampai pada penghayatan suatu nilai. Tahapan dalam Proses 
Internalisasi (Nugraheni, 2016) sebagai berikut :

a. Tahap receiving (menyimak). Pada tahap ini seseorang aktif dan sensitif menerima stimulus dan menghadapi fenomen-fenomena, sedia menerima secara aktif dan selektif dalam memilih fenomena.

b. Tahap responding (menanggapi). Pada tahap ini seseorang sudah mulai bersedia menerima dan menanggapi secara aktif stimulus dalam bentuk respon yang nyata

c. Tahap valuing (memberi nilai). Pada tahap ini, seseorang sudah mampu menangkap stimulus itu atas dasar nilai-nilai yang terkandung di dalamnya dan mulai mampu untuk menyusun persepsi tentang objek.

d. Tahap organization (mengorganisasikan nilai) Yaitu satu tahap yang lebih kompleks dari tahap ketig diatas. Seseorang mulai mengatur sistem nilai yang ia terima dari luar untuk diorganisasikan (ditata) dalam dirinya sehingga sistem nilai itu menjadi bagian yang tidak terpisahkan dalam dirinya.

e. Tahap characterization (karakterisasi nilai). Tahap ini ditandai dengan ketidakpuasan seseorang untuk mengorganisir sistem nilai yang diyakininya dalam hidupnya secara maapan, ajek dan konsisten sehingga tidak dapat dipisahkan lagi dengan kepribadiannya.

\section{Proses Internalisasi Mahasiswi Muslimah Bercadar di Fakultas Ekonomi Universitas Negeri Makassar}

a) Tahap Menyimak

Dalam tahap ini mahasiswi muslimah menyimak berbagai nilai-nilai dengan mempelajari lebih jauh atau menggali lebih dalam lagi, ajaran-ajaran Islam tentang menutup aurat utamanya yang menyangkut tentang cadar. Hasil wawancara mengungkapkan bahwa mahasiswi muslimah bercadar aktif mengikuti berbagai kajian-kajian keislaman dan lembaga-lembaga dakwah Islam baik yang berada di dalam kampus maupun di laur kampus. Seperti Lembaga Dakwah SC Al Huda yang berada dalam lingkup Kampus, Lembaga Dakwah Wahdah yang berada di luar kampus, dan kajian- kajian keislaman seperti Kajian Salafi. Selain itu, mahasiswi muslimah secara langsung memperhatikan kehidupan muslimah bercadar utamanya yang berada di lingkup kampus sendiri.

b) Tahap Menanggapi

Tahap ini seseorang sudah mulai bersedia menerima dan menanggapi secara aktif stimulus dalam bentuk respon yang nyata. Proses internalisasi mahasiswi muslimah bercadar dalam tahap ini yakni dengan menyimak berbagai nilai- nilai yang ia terima pada tahap sebelumnya mahasiswi muslimah mulai memberikan respon yang nyata yaitu dengan keyakinan dalam diri untuk menggunakan cadar sebagai suatu kewajiban yang harus dijalankan sesuai tuntunan Al Qur'an dan Hadizt berdasarkan nilai-nilai yang telah dipahami dan ditelaah dari berbagai sumber.

c) Tahap Menilai

Proses internalisasi mahasiswi muslimah bercadar dalam tahap valuing (menilai) ini, didasarkan pada pemahaman dan pemaknaan mereka tentang cadar itu sendiri. Hal tersebut berdasarkan hasil wawancara dengan informan yang mengungkap tentang berbagai persepsi dan pandangan informan terkait pemaknaan mereka tentang cadar. Seperti cadar yang merupakan penutup dan pelindung serta pemahaman mereka tentang hukum cadar dari berbagai literatur yang telah di telaah.

d) Tahap Mengorganisasi

Proses internalisasi mahasiswi muslimah bercadar dalam tahap ini yakni dengan mengenakan jilbab yang disertai dengan penggunaan cadar sesuai syariat Islam, maka tidaklah mungkin bagi seorang muslimah akan berperilaku yang tidak mencerminkan seorang muslimah sejati sesuai dengan tuntunan Al Qur'an dan Sunnah. Sehingga penggunaan cadar bagi informan sebagai sarana atau mekanisme kontrol diri.

e) Tahap Karakterisasi

Keterpaduan semua sistem nilai yang telah dimiliki seseorang yang mempengaruhi pola 
kepribadiannya dan tingkah lakunya. Mahasiswi muslimah telah memiliki kebulatan sikap dalam wujud menjadikan perintah Allah SWT yang terterah di dalam Al Qur'an dan As Sunnah serta berbagai Hadiz-Hadiz, yang menyangkut tentang kewajiban menutup aurat bagi seorang muslimah yang disempurnakan dengan penggunaan cadar sebagai pegangan hidupnya. Keterpaduan sistem nilai (cadar) yang telah mereka yakini mempengaruhi pola tingkah lakunya.

\section{Adaptasi Sosial Mahasiwi Muslimah Bercadar di Fakultas Ekonomi Universitas Negeri Makassar Penampilan Nyata melalui Sikap}

Menurut mahasiswi muslimah bercadar adaptasi dalam penampilan nyata melalui sikap dan tingkah laku diwujudkan dalam bentuk penampilan nyata seperti aktualisasi diri, keterampilan menjalin hubungan, serta kesediaan untuk terbuka pada orang lain.

1. Penyesuaian Diri dengan Berbagai Kelompok

Seseorang dapat menyesuaikan diri dengan baik terhadap berbagai kelompok, baik kelompok teman sebaya maupun kelompok orang dewasa. Mahasiswi muslimah bercadar dalam hal ini melakukan penyesuaian diri terhadap berbagai kelompok dalam bentuk kerja sama dalam kelompok, setia kawan dan senantiasa bertanggungjawab dalam segala hal.

\section{Sikap Sosial}

Individu dapat menunjukkan sikap yang menyenangkan terhadap orang lain, terhadap partisipasi sosial, serta terhadap perannya dalam kelompok, maka individu akan menyesuaikan diri dengan baik secara sosial. Muslimah bercadar dalam hal ini melakukan adaptasi sosial dengan menerapkan sikap sosial dalam kehidupannya seperti dalam bentuk berpartisipasi dalam kegiatan sosial dan menghargai dan menghormati orang lain. Dalam penelitian ini peneliti menggunakan konsep teori Konstruksi Sosial. Teori yang dikembangkan oleh Peter L Berger ini berangkat dari paradigma konstruktivis yang memandang realitas sosial merupakan konstruksi sosial yang diciptakan oleh individu. Relevansi teoritis konstruksi sosial perspektif Peter L. Berger dalam konteks riset proses internalisasi mahasiswi muslimah bercadar di Fakultas Ekonomi Universitas Negeri Makassar melalui momen dialektis yaitu internalisasi.

Proses internalisasi dapat diperoleh individu melalui proses sosialisasi primer dan sekunder. Proses Internalisasi dalam sosialisasi individu dilangsungkan dengan beberapa tahapan, yakni menyimak, menanggapi, menilai, mengorganisasikan, dan karakterisasi nilai. Selanjutnya, Adaptasi Sosial Mahasiswi Muslimah Bercadar di Fakultas Ekonomi Universitas Negeri Makassar. Relevansi teoritis konstruksi sosial perspektif Peter L. Berger dalam konteks riset adaptasi sosial mahasiswi muslimah bercadar di Fakultas Ekonomi Universitas Negeri Makassar melalui momen dialektis yaitu eksternalisasi. Eksternalisasi dalam penelitian ini merupakan suatu momen dimana seseorang melakukan adaptasi terhadap lingkungannya. Eksternalisasi, sebagai upaya pencurahan atau ekspresi diri manusia ke dalam dunia, baik kegiatan mental maupun fisik. Dalam proses ini sarana yang digunakan adalah bahasa dan tindakan. Manusia menggunakan bahasa untuk melakukan adaptasi dengan dunia sosio-kulturalnya dan kemudian tindakannya juga disesuaikan dengan dunia sosio-kulturalnya. Melalui proses eksternalisasi yang kokoh, para musimah bercadar harus mampu beradaptasi terhadap lingkungannya, baik dalam lingkup perkuliahan maupun dalam masyarakat umum.

\section{SIMPULAN}

Proses internalisasi mahasiswi muslimah bercadar di Fakultas Ekonomi Universitas Negeri Makassar dilakukan dengan melalui beberapa tahap yaitu tahap menyimak, tahap menanggapi, tahap menilai, tahap mengorganisasi dan tahap karakterisasi. Adapun adaptasi sosial mahasiswi muslimah bercadar dilakukan dengan : a) Penampilan nyata, b) Penyesuaian diri dengan kelompok, c) Sikap sosial.

\section{DAFTAR PUSTAKA}

B.A Yahya. 2006. Fatwa-Fatwa Tentang Wanita 3. Jakarta : Darul Haq, hal. 106. Bungin, Burhan. 2001. Konstruksi Sosial Media Massa. Jakarta : PrenadaMedia Group 
Hurlock, Elizabeth B. 1980. Psikologi Perkembangan : Suatu Pendekatan Sepanjang Rentang Kehidupan. Jakarta : Gramedia, hal. 287.

Poloma, Margaret. 2003. Sosiologi Kontemporer . Jakarta : Raja Grafindo Persada, hal. 301.

Scott, J. 1971. Internalization of Norms : A Sociological Theory of Moral Commitment. Englewood Cliff, N.J : Paentice-Hall, hal. 12.

Soyomukti, Nurani. Pengantar Sosiologi. Yogyakarta : Pustaka Pelajar, hal. 344.

Catmi, Nugraheni. 2016. Pelaksanaan Internalisasi Nilai-Nilai Islam Kepada Siswa Autis di SLB C-CI Yakut Purwokerto Tahun Pelajaran 2015/2016. Pendidikan Agama Islam. Fakultas Agama Islam. Universitas Muhammadiyah Purwokerto.

As-Salam Al-Qur'an dan Terjemahannya Edisi 1000 Doa. 2012. Jakarta : Mizan Media Utama (MMU), hal. 427.

Kamus Besar Bahasa Indonesia. 1989. Pusat Pembina dan Pengembangan Bahasa Departement Pendidikan dan Kebudayaan. Jakarta : Balai Pustaka, hal. 336.

Pusat Bahasa Departemen Pendidikan Nasional. 2015. Kamus Besar Bahasa Indonesia (Edisi Ketiga). Jakarta : Balai Pustaka, hal. 439. 